\title{
ANALISIS KELAYAKAN PENGEMBANGAN USAHA PENGGILINGAN PADI PD. ANCOL JAYA CIANJUR
}

\author{
Suharyanto, Rifqi Al-Farisi, Hendra Permana \\ Program Studi Teknik Industri \\ Universitas Suryakancana Cianjur \\ yanto_sy2008@yahoo.com
}

\begin{abstract}
ABSTRAK
Usaha penggilingan padi sampai dengan saat ini masih menjadi salah satu usaha yang cukup menjanjikan di Kabupaten Cianjur. Oleh karena itu pengembangan usaha ini masih terbuka lebar, untuk itu perlu dilakukan studi kelayakan dengan cermat sehingga dapat membantu pemilik usaha ini untuk memperbaiki kinerjanya. Penelitian ini berupa analisis kelayakan pengembangan usaha penggilingan padi PD. Ancol Jaya khususnya dari aspek finansial, dengan kriteria kelayakan Net Present Value (NPV), Internal Rate of Return (IRR), Net Benefit/Cost (B/C) dan Payback Periode (PP). Analisis aspek finansial dilakukan untuk dua proyeksi kondisi yang berbeda yakni pada keadaan normal (kenaikan produksi 10\%) serta keadaan optimis (kenaikan produksi 25\%) per tahun. Hasil analisis menunjukkan nilai Net Present Value (NPV) lebih dari nol yaitu sebesar Rp. 1.088.835.228,83 pada keadaan normal dan Rp. 1.604.304.738,04 pada keadaan optimis, nilai Internal Rate of Return (IRR) lebih dari tingkat discount rate (13,5\%) yaitu sebesar $64 \%$ pada keadaan normal dan $76 \%$ pada keadaan optimis, serta nilai Net Benefit/Cost (B/C) lebih besar dari satu, yakni 2,919 pada keadaan normal dan 3,646 pada keadaan optimis. Sedangkan Payback Periode (PP) kurang dari umur usaha yaitu selama dua tahun lima belas hari untuk keadaan normal dan satu tahun sepuluh bulan tiga hari untuk keadaan optimis. Dari analisis tersebut menunjukkan bahwa kelayakan usaha penggilingan padi di perusahaan PD. Ancol Jaya secara finansial layak untuk dijalankan baik dalam proyeksi/ keadaan normal (kenaikan produksi 10\%) maupun proyeksi/ kondisi optimis (kenaikan produksi 25\%).
\end{abstract}

Kata Kunci : analisis kelayakan usaha, aspek finansial, kondisi optimis.

\section{PENDAHULUAN}

\section{A. Latar Belakang Masalah}

Indonesia dikenal sebagai negara agraris karena sebagian besar penduduk Indonesia mempunyai pencaharian di bidang pertanian. Sektor pertanian merupakan sektor yang menjadi tumpuan hidup sebagian besar masyarakat Indonesia. Pertanian di Indonesia menghasilkan berbagai macam tumbuhan komoditi diantaranya adalah padi. Usaha tani padi menyediakan lapangan pekerjaan dan sebagai sumber pendapatan bagi sekitar 21 juta rumah tangga pertanian. Data statistik pada tahun 2011 menunjukkan bahwa $38 \%$ penduduk Indonesia bekerja di bidang pertanian. Hal ini didasarkan pada kenyataan bahwa negara ini memiliki lahan seluas lebih dari 13 juta ha lahan siap panen, dimana sebagian besarnya dapat ditemukan di Pulau Jawa.

Kebutuhan masyarakat terhadap hasil pertanian, terutama beras menjadi permasalahan utama yang harus diatasi saat ini. Beras merupakan bahan pangan pokok bagi lebih dari $95 \%$ penduduk indonesia. Selain itu, beras juga merupakan komoditas politik yang sangat strategis, sehingga produksi beras dalam negeri menjadi tolok ukur ketersediaan pangan bagi Indonesia. Oleh sebab itu, perhatian terhadap produksi, kualitas, distribusi, dan kesejahteraan para pelaku sektor pertanian harus mendapat perhatian dari pemerintah.

Perancangan program surplus beras nasional 10 juta ton pada tahun 2014, memberi arti bahwa pemerintah memberi perhatian pada sektor pertanian. Perancangan program ini membuat setiap wilayah menentukan target produksinya sendiri. Salah satu wilayah yang menetapkan target produksi beras adalah Kabupaten Cianjur. Pada tahun 2011 dengan luas tanam 157.750 ha dan luas panen 144.913 ha, Kabupaten Cianjur dapat menghasilkan 839.773 ton beras. 
Target peningkatan produksi Kabupaten Cianjur sebesar 2.466 .594 ton gkg pada tahun 2014. Target di ditentukan sebagai upaya untuk mendukung peningkatan produksi beras Jawa Barat serta program surplus beras nasional 10 juta ton pada 2014 . Tetapi dalam upaya tersebut banyak kendala yang dialami, diantaranya adalah mundurnya masa tanam padi pada tahun 2012/2013, dimana seharusnya mulai tanam bulan Oktober, dibeberapa daerah mundur ke bulan November bahkan Desember.

Selain itu, untuk mendukung peningkatan produksi beras perlu adanya penanganan pasca panen serta proses penggilingan padi yang baik. Karena dengan upaya tersebut, dapat menghasilkan produksi beras yang optimal. Penggilingan padi merupakan sarana produksi pangan yang sangat penting, baik dalam pemberdayaan masyarakat maupun penciptaan lapangan kerja. Selain itu, penggilingan padi merupakan suatu proses perubahan bahan baku menjadi hasil olahan primer.

Tingginya target produksi padi di Cianjur, tidak sebanding dengan dengan tingginya produksi penggilingan padi. Itu terjadi karena banyak penggilingan padi yang gulung tikar. Hal itu disebabkan karena teknologi yang digunakan serta kelayakan penggilingan itu sendiri baik secara pemasaran, keuangan, manajemen serta teknis yang tidak diperhitungkan secara matang. Akan tetapi banyak para pemilik penggilingan yang tidak tahu cara menganalisa layak atau tidaknya usahanya. Penggilingan padi PD. Ancol Jaya merupakan salah satu penggilingan padi yang berada di Kabupaten Cianjur. Meskipun penggilingan tersebut masih berskala kecil, akan tetapi diharapkan dapat mendukung serta membantu dalam program peningkatan produksi beras di Kabupaten Cianjur. Oleh sebab itu, perlu adanya analisis kelayakan pengembangan usaha penggilingan padi yang baik secara pemasaran, manajemen, teknis, maupun keuangan.

\section{B. PERUMUSAN MASALAH}

Penggilingan padi PD. Ancol Jaya merupakan salah satu penggilingan padi yang berada di Desa Maleber Kecamatan Karangtengah Kabupaten Cianjur. Untuk tetap bisa menjalankan sekaligus untuk rencana pengembangan usahanya, perlu adanya analisis kelayakan agar dapat diketahui manfaat bersih yang diperoleh perusahaan. Analisis kelayakan usaha dilakukan untuk mengetahui apakah pengembangan usaha penggilingan padi PD. Ancol Jaya layak untuk dijalankan jika dilihat dari aspek non finansial dan finansial. Dari aspek finansial, pengukuran kelayakan menggunakan indikator Net Present Value (NPV), Internal Rate of Return (IRR), Net Benefit-Cost Ratio ( $B / C)$, dan Payback Periode (PP). Untuk mengetahui kelayakan penggilingan padi ini juga dilakukan analisis dari berbagai aspek non finansial seperti aspek pasar, aspek teknis, aspek manajemen hukum, aspek sosial ekonomi budaya, dan aspek lingkungan.

Berdasarkan uraian diatas, maka terdapat beberapa permasalahan pokok yang akan dibahas dalam penelitian ini, yaitu:

1. Bagaimana kelayakan pengembangan usaha penggilingan padi PD. Ancol Jaya dilihat dari sisi non finansial (aspek pasar, teknis, manajemen, hukum, sosial ekonomi budaya, dan lingkungan)?

2. Bagaimana kelayakan pengembangan usaha penggilingan padi PD. Ancol Jaya dilihat dari sisi finansial Net Present Value (NPV), Internal Rate of Return (IRR), Net Benefit-Cost Ratio (B/C), dan Payback Periode (PP)?

\section{Tujuan Dan Manfaat}

Berdasarkan perumusan masalah yang telah dipaparkan di atas, maka tujuan dari penelitian ini adalah sebagai berikut:

1. Mengetahui kelayakan pengembangan usaha penggilingan padi PD. Ancol Jaya dilihat dari sisi non finansial (aspek pasar, teknis, manajemen, hukum, sosial ekonomi budaya, dan lingkungan)?

2. Mengetahui kelayakan pengembangan usaha penggilingan padi PD. Ancol Jaya 
dilihat dari sisi finansial Net Present Value (NPV), Internal Rate of Return (IRR), Net Benefit-Cost Ratio (B/C), dan Payback Periode (PP)?

Adapun manfaat penelitian ini adalah :

1. Bagi perusahaan penggilingan padi PD. Ancol Jaya berguna sebagai bahan masukan yang dapat dipertimbangkan dalam hal pengambilan keputusan terkait dengan kegiatan operasional dan pengembangan usahanya.

2. Bagi Pemerintah Daerah Kabupaten Cianjur, berguna sebagai bahan pertimbangan dalam menetapkan kebijakan pengembangan usaha mikro, kecil dan menengah.

3. Bagi pembaca dapat memberikan informasi mengenaiusaha penggilingan padi dan memberikan gambaran bagi investor untuk melakukan investasi pada usaha penggilingan padi di Kabupaten Cianjur.

\section{Batasan Masalah}

Penelitian dilakukan di Desa Maleber, Kecamatan Karangtengah, Kabupaten Cianjur yaitu pada perusahaan penggilingan padi PD. Ancol Jaya. Penelitian ini akan difokuskan pada analisis kelayakan usaha ditinjau dari aspek finansial dan non finansial. Pada aspek finansial yang akan diteliti adalah pengukuran kelayakan menggunakan indikator Net Present Value (NPV), Internal Rate of Return (IRR), Net Benefit-Cost Ratio (B/C), dan Payback Periode (PP). Sedangkan pada aspek non finansial, aspek yang akan diteliti adalah aspek pasar, teknis, manajemen, hukum, sosial ekonomi budaya, dan lingkungan.

\section{LANDASAN TEORI}

Suatu bisnis erat kaitannya dengan kegiatan investasi. Pihak yang menginvestasikan modalnya tentu harus mengkaji secara mendalam bisnis tersebut. Oleh karena itu, disetiap bisnis perlu dilakukan analisis berupa studi kelayakan bisnis beserta aspek-aspeknya untuk melihat secara menyeluruh berbagai aspek mengenai kemampuan suatu bisnis dalam memberikan manfaat terhadap modal. Adapun aspek-aspek kelayakan bisnis yang dianalisis antara lain: aspek pasar, aspek teknis, aspek manajemen, hukum, aspek sosial, ekonomi, budaya, aspek lingkungan serta aspek finansial.

\section{A. Analisis Kelayakan Bisnis}

Nurmalina et al. (2009) mengungkapkan bahwa bisnis secara umum merupakan suatu kegiatan yang mengeluarkan biaya-biaya dengan harapan akan memperoleh hasil/benefit dan secara logika merupakan wadah untuk melakukan kegiatan-kegiatan perencanaan, pembiayaan dan pelaksanaan dalam satu unit. Menurut Gray et al. (1992) dalam Nurmalina et al. (2009), kegiatan investasi diartikan sebagai kegiatan yang dapat direncanakan dan dilaksanakan dalam satu bentuk kesatuan dengan mempergunakan sumber-sumber untuk mendapatkan hasil/ benefit.

Studi kelayakan bisnis merupakan penelaahan atau analisis tentang apakah suatu kegiatan investasi memberikan manfaat atau hasil bila dilaksanakan (Nurmalina et al. 2009). Dengan demikian studi kelayakan bisnis erat kaitannya dengan keputusan investasi. Senada dengan pernyataan tersebut, Husnan dan Muhammad (2005) juga mendefinisikan studi kelayakan investasi sebagai suatu penelitian tentang dapat tidaknya proyek investasi dilaksanakan secara menguntungkan dengan indikasi adanya manfaat bagi masyarakat luas yang bias terwujud dari penyerapan tenaga kerja, pemanfaatan sumberdaya yang melimpah ataupun manfaat untuk pemerintah berupa penghematan atau penambahan devisa.

\section{B. Aspek-Aspek Analisis Kelayakan Bisnis}

Menurut Nurmalina et al. (2009), penilaian dalam studi kelayakan bisnis dilakukan secara menyeluruh dari berbagai aspek yaitu dari aspek non finansial serta 
aspek finansial (keuangan). Beberapa aspek non finansial yang merupakan aspek dalam studi kelayakan bisnis dianalisis secara kualitatif dan tidak terkait dengan biaya dan manfaat yang bersifat kuantitatif. Aspek non finansial yang akan dibahas dalam penelitian ini meliputi aspek pasar, aspek teknis, aspek manajemen, hukum, aspek sosial ekonomi budaya, dan aspek lingkungan .

\section{Aspek Pasar}

Pasar meliputi keseluruhan pembeli potensial yang akan memenuhi kebutuhan dan keinginannya, dimana pembeli tersebut bersedia dan mampu membeli alat-alat pemuas melalui pertukaran (Kotler, 1988) diacu dalam Sudiyono (2002). Menurut Husnan dan Muhammad (2005) aspek pasar mengkaji tentang:

a. Permintaan (Demand)

Menurut Kotler (1988) dalam Husnan dan Muhammad (2005), jumlah yang diminta untuk jumlah komoditi yang ingin dibeli oleh semua rumah tangga disebut permintaan. Dari konsep permintaan tersebut dapat diketahui bahwa variabel-variabel yang mempengaruhi permintaan adalah harga komoditi tersebut harga komoditi barang lain, pendapatan rata-rata rumah tangga, selera, distribusi pendapatan diantara rumah tangga, dan jumlah penduduk.

b. Program pemasaran

Menurut Kotler (1988) dalam Husnan dan Muhammad (2005), program pemasaran sering disebut sebagai bauran pemasaran (marketing mix), yang terdiri dari empat komponen yaitu produk (product), harga (price), distribusi (distribution), dan promosi (promotion). Program pemasaran mencakup strategi pemasaran yang akan digunakan bauran pemasaran serta identifikasi siklus kehidupan produk, pada tahap apa produk akan dibuat.

Sebuah perusahaan sebelum memproduksi sebuah produk harus terlebih dahulu melihat permintaan yang benar-benar dilakukan oleh konsumen, penawaran yang dilakukan oleh produsen dalam industri tersebut, market share perusahaan selama ini, serta peluang market share yang masih bisa ditingkatkan. Hal ini perlu dilakukan agar produk yang ditawarkan perusahaan tepat sasaran dan menghindari kerugian bagi perusahaan.

Pesaing juga akan menentukan keberlanjutan sebuah bisnis sehingga perlu dilakukan analisis pesaing. Pesaing merupakan suatu perusahaan lain yang mempunyai salah satu atau lebih ciri-ciri:

1. Perusahaan yang menawarkan produk dan harga yang sama di pasar,

2. Perusahaan yang membuat produk atau kelas produk yang sama,

3. Perusahaan yang membuat produk dan memasok yang sama,

4. Perusahaan yang memperebutkan uang dari konsumen yang sama.

\section{Aspek Teknis}

Aspek teknis merupakan analisis yang berhubungan dengan input proyek (penyediaan) dan output (produksi) berupa barang dan jasa, dimana aspek teknis berkaitan dengan proses pembangunan proyek secara teknis dan pengoperasiannya setelah proyek tersebut selesai dibangun (Husnan dan Muhammad, 2005). Analisis teknis akan dapat menentukan hasil-hasil yang potensial di areal proyek, pengujian fasilitas-fasilitas pemasaran dan penyimpanan yang dibutuhkan untuk mendukung dalam pelaksanaan proyek, pengujian sistem- sistem pengolahan yang dibutuhkan.

Menurut Nurmalina et al. (2009) beberapa hal yang perlu dikaji dalam aspek teknis antara lain lokasi bisnis, luas produksi, proses produksi, layout, dan pemilihan jenis teknologi dan equipment.

a. Lokasi Bisnis

Variabel yang mempengaruhi pemilihan lokasi bisnis ini terdiri atas variabel utama dan variabel bukan utama yang dimungkinkan untuk berubah. Variabel utama antara lain ketersedian bahan baku, letak pasar yang dituju, tenaga 
listrik dan air, supply tenaga kerja, fasilitas transportasi

b. Luas Produksi

Beberapa faktor yang mempengaruhi penentuan luas produksi yaitu batasan permintaan, tersedianya kapasitas mesin, jumlah dan kemampuan tenaga kerja pengelolaan proses produksi, kemampuan financial dan manajemen perusahaan, dan kemungkinan adanya perubahan teknologi produksi di masa yang akan datang.

c. Proses Produksi

Proses produksi terdiri atas tiga jenis yaitu proses produksi yang terputusputus, proses produksi yang kontinu, dan proses produksi kombinasi.

d. Layout

Layout ini mencakup layout site, layout pabrik, layout bangunan bukan pabrik, dan fasilitas-fasilitanya. Kriteria-kriteria yang dapat digunakan yakni kosistensi dengan teknologi produksi, arus produk dalam proses produksi yang lancar dari satu proses ke proses lain, penggunaan ruangan yang optimal, kemudahan melakukan ekspansi, meminimisasi biaya produksi, dan memberikan jaminan yang cukup untuk keselamatan tenaga kerja.

e. Pemilihan Jenis Teknologi dan Equipment

Pada dasarnya pemilihan teknologi ini berpatokan pada seberapa jauh derajat mekanisasi yang diinginkan dan manfaat ekonomi yang diharapkan. Pemilihan mesin dan peralatan serta jenis teknologi mempunyai hubungan yang erat sekali karena pemilihan mesin wajib mengikuti ketentuan jenis teknologi yang telah ditetapkan walaupun juga mempertimbangkan faktor non teknologi lainnya seperti keadaan infrastruktur dan fasilitas pengangkutan mesin, keadaan fasilitas pemeliharaan dan perbaikan mesin dan peralatan yang ada di sekitar lokasi bisnis, kemungkinan memperoleh tenaga ahli yang akan mengelola mesin dan peralatan tersebut.

\section{Aspek Manajemen}

Aspek Manajemen meneliti sistem manajerial suatu usaha antara lain kesanggupan dan keahlian staf dalam menangani masalah proyek. Evaluasi aspek manajemen operasional bertujuan untuk menentukan secara efektif dan efisien mengenai bentuk badan usaha yang dipilih, struktur organisasi yang akan digunakan, jenis-jenis pekerjaan yang diperlukan agar usaha tersebut dapat berjalan dengan lancar serta kebutuhan biaya gaji dan upah tenaga kerja. Dengan demikian, analisis aspek manajemen dibagi kedalam dua kelompok yaitu manajemen dalam pembangunan bisnis dan manajemen dalam masa operasi.

\section{Aspek Hukum}

Analisis aspek hukum diperlukan dengan mempertimbangkan bentuk badan hukum dari badan usaha yang telah dibangunnya. Pertimbangan ini didasarkan dari kekuatan hukum, konsekuensi, dan mempelajari jaminan-jaminan yang bisa disediakan bila akan menggunakan sumber dana berupa pinjaman, berbagai akta, sertifikat, dan izin. Ketika perusahaan telah melakukan perijinan, maka perusahaan telah terdaftar sebagai badan usaha dan diakui keberadaannya oleh pemerintah setempat dan pusat.

5. Aspek Sosial, Ekonomi, Budaya

Pada aspek ini, analisis yang dilakukan akan menilai dampak sosial, ekonomi, dan budaya terhadap masyarakat keseluruhan. Beberapa pertimbangan sosial yang harus dipikirkan secara cermat agar dapat menentukan apakah suatu proyek yang diusulkan tanggap terhadap keadaan sosial seperti penciptaan kesempatan kerja yang merupakan masalah terdekat dari suatu wilayah (Gittinger,1986). Nurmalina et al. (2009) menambahkan bahwa dalam menganalisis aspek sosial perlu mempertimbangkan pola dan kebiasaan sosial yang lebih luas dari adanya investasi proyek. 


\section{Aspek Lingkungan}

Pembangunan suatu usaha tentu akan memberikan dampak bagi lingkungan baik secara langsung maupun tidak langsung. Analisis aspek lingkungan diperlukan untuk menganalisis dampak tersebut. Nurmalina et al. (2009) menyatakan bahwa dalam analisis aspek lingkungan perlu diperhatikan bagaimana pengaruh keberadaan bisnis terhadap lingkungan sekitar.

\section{Analisis Finansial}

Menurut Husnan dan Muhammad (2005), analisis finansial (financial analysis) merupakan analisis yang membatasi manfaat dan pengorbanan dari sudut pandang perusahaan. Analisis aspek finansial merupakan bagian dari analisis studi kelayakan bisnis yang sangat diperlukan untuk menentukan manfaat yang diterima dari bisnis tersebut. Selain itu, aspek ini juga memperhitungkan penerimaan dan pengeluaran yang diperoleh selama suatu usaha berjalan. Beberapa data yang diperlukan: biaya investasi, biaya operasional yang terdiri dari biaya tetap dan biaya variabel serta penerimaan yang diperoleh selama umur bisnis. Data-data ini akan diolah dengan menggunakan analisis kelayakan bisnis berupa kriteria investasi seperti Net Present Value (NPV), Net Benefit-Cost Ratio (Net B/C), Internal Rate of Return (IRR), dan Payback Period (PP).

\section{Biaya dan Manfaat}

Biaya adalah segala sesuatu yang mengurangi tujuan bisnis yakni manfaat. Menurut Gittinger (1986) biaya yang digunakan dalam suatu bisnis dapat digolongkan ke dalam tujuh kelompok yakni :

a. Barang-barang fisik, biaya jenis ini pada umumnya mudah diidentifikasi. Tenaga Kerja

b. Lahan, tidak terlalu sulit untuk menetukan lokasi tanah yang cocok untuk bisnis maupun jumlah yang dibutuhkan.

c. Cadangan-cadangan tak terduga, biaya tak terduga dibagi kedalam biaya tak terduga fisik dan biaya tak terduga harga.

d. Jasa Pinjaman, biaya jasa pinjaman pada analisis keuangan terdiri dari bunga dan pelunasan kembali pinjamannya.

e. Biaya-Biaya Tidak Diperhitungkan, yaitu semua biaya yang dikeluarkan pada waktu yang lampau yang didasarkan pada suatu usulan investasi yang baru biasanya biaya ini juga disebut sebagai Sunk cost.

Manfaat dapat dibagi ke dalam Tangible Banefit, Indirect Benefit, dan Intangible Benefit (Nurmalina et al. 2009).

a. Tangible Benefit, merupakan manfaat yang dapat diukur.

b. Indirect Benefit, yakni manfaat yang dirasakan di luar bisnis itu sendiri sehingga mempengaruhi keadaan eksternal bisnis.

c. Intangible Benefit, yakni manfaat yang riil namun sulit diukur contohnya manfaat keindahan, kenyamanan, dan kesegaran pada bisnis pertamanan

\section{Kriteria Kelayakan Bisnis}

Studi kelayakan bisnis pada dasarnya bertujuan untuk menentukan kelayakan bisnis berdasarkan kriteria investasi yang dapat digunakan dalam analisis ini yaitu:

a. Net Present Value (NPV).

b. Net Benefit-Cost Ratio $($ Net B/C).

c. Internal Rate of Return (IRR).

d. Payback Period (PP).

\section{METODOLOGI PENELITIAN}

Penelitian ini dilakukan pada sebuah perusahaan penggilingan padi di Desa Maleber Kecamatan Karangtengah Kabupaten Cianjur Jawa Barat, yaitu perusahaan 
penggilingan padi PD. Ancol Jaya. Pemilihan lokasi dengan pertimbangan bahwa penggilingan padi PD. Ancol Jaya merupakan penggilingan padi yang berlokasi strategis, berdekatan dengan sentara produksi padi serta daerah pemasaran. Penelitian dilaksanakan pada bulan Maret-April tahun 2013.

\section{A. Tahapan Penelitian}

Tahapan penelitian tersaji dalam bentuk diagram alir sebagai berikut:

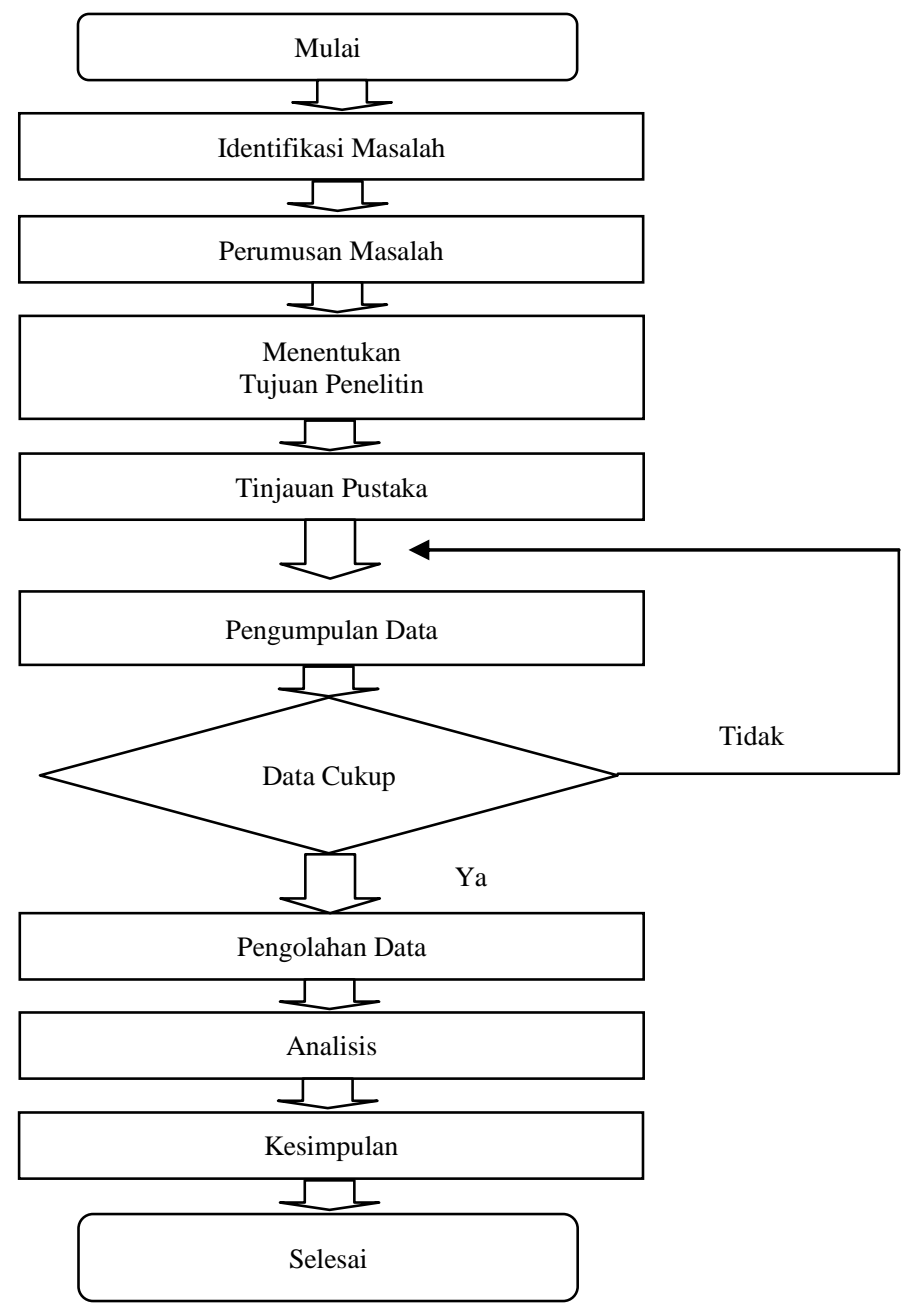

Gambar 1. Diagram Alur Penelitian

\section{B. Jenis dan Sumber Data}

Penelitian menggunakan data primer dan data sekunder baik yang bersifat kualitatif maupun kuantitatif. Data primer meliputi :

1. Data keuangan yang mencakup penerimaan, biaya-biaya operasional dan biaya investasi yang telah dikeluarkan.

2. Aspek-aspek non finansial seperti aspek pasar, teknis, aspek manajemen, hukum, aspek sosial, ekonomi, dan budaya, serta aspek lingkungan.

Data sekunder sebagai penunjang penelitian ini diperoleh dari dokumen perusahaan dan instansi terkait seperti BPS (Badan Pusat Statistik) Nasional maupun Kabupaten Cianjur, Dinas Koperasi, Pertanian, Perindustrian dan Perdagangan Kabupaten Cianjur, Kantor Desa Maleber, media massa dan media elektronik, studi kepustakaan serta berbagai literatur lainnya. 


\section{Metode Pengumpulan Data}

Pengumpulan data, baik data primer maupun data sekunder dilakukan dari Bulan Maret 2013 hingga Bulan April 2013. Pengumpulan data dilakukan sendiri oleh peneliti. Teknik pengumpulan data yang dilakukan antara lain wawancara langsung, pengamatan langsung, browsing internet, dan observasi lapangan.

\section{HASIL DAN PEMBAHASAN}

\section{A. Sejarah dan Perkembangan Perusahaan}

Perusahaan penggilingan padi PD. Ancol Jaya merupakan salah satu penggilingan padi yang berada di Cianjur dan beralamatkan di Jalan KH. Opo Mustopa No. 24 RT/RW 01/02, Desa Maleber, Kecamatan Karangtengah, Kabupaten Cianjur, Jawa Barat. Usaha yang didirikan oleh H. Baba Badrudin (Alm) didirikan tahun 1995. Pada tahun 2006, perusahaan melakukan penambahan kapasitas dengan membeli sejumlah mesin untuk proses produksi seperti mesin penggerak utama, conveyor serta mesin giling pemutih. Pembelian mesin ini merupakan salah satu kebijakan perusahaan untuk mengembangkan usahanya agar lebih efektif dan efisien guna mendapatkan keuntungan maksimal.

Adapun luas lahan yang PD. Ancol Jaya seluas seribu sembilan ratus meter persegi $\left(1900 \mathrm{~m}^{2}\right)$, meliputi luas bangunan pabrik, kantor perusahaan, mess karyawan, musholla, toilet karyawan, dan lahan terbuka sebagai tempat penjemuran atau proses pengeringan padi.

\section{B. Aspek Non Finansial}

\section{Organisasi Perusahan}

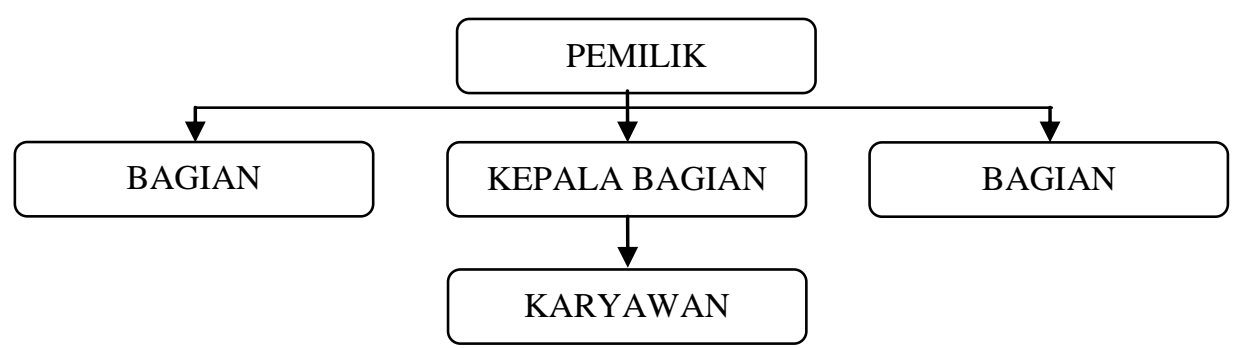

Gambar 2. Struktur Organisasi Perusahaan PD. Ancol Jaya

Berikut tabel kompetensi sumber daya manusia yang dimiliki perusahaan.

Tabel 1. Kompetensi Pekerja PD. Ancol Jaya

\begin{tabular}{|c|c|c|c|c|}
\hline No & $\begin{array}{c}\text { Jenis } \\
\text { Pekerjaan }\end{array}$ & Status & Kualifikasi & Jumlah \\
\hline 1. & $\begin{array}{l}\text { Kepala } \\
\text { Bagian } \\
\text { Produksi }\end{array}$ & $\begin{array}{c}\text { Karyawan } \\
\text { Tetap }\end{array}$ & $\begin{array}{l}\text { - Mampu menyusun rencana } \\
\text { - Msaha ke depan. } \\
\text { - } \text { yampu mengelola tenaga kerja } \\
\text { - Memahami proses produksi dan } \\
\text { kualitas produk } \\
\text { - Pekerja keras. } \\
\text { - Mampu bekerja dalam tim. } \\
\text { - Memahami mesin dan peralatan } \\
\text { - Memiliki kesungguhan dalam } \\
\text { bekerja }\end{array}$ & 1 \\
\hline
\end{tabular}




\begin{tabular}{|c|c|c|c|c|}
\hline 2. & $\begin{array}{c}\text { Bagian } \\
\text { Pemasaran }\end{array}$ & $\begin{array}{c}\text { Karyawan } \\
\text { Tetap }\end{array}$ & $\begin{array}{l}\text { - Mampu melihat dan menangkap } \\
\text { peluang pasar. } \\
\text { - Memiliki kemampuan } \\
\text { komunikasi dan menjalin } \\
\text { kemitraan. } \\
\text { - Memahami arti penting } \\
\text { pemasaran. } \\
\text { - Pekerja keras. } \\
\text { - Mampu bekerja dalam tim. } \\
\text { - Memiliki kesungguhan dalam } \\
\text { bekerja }\end{array}$ & 1 \\
\hline 3. & $\begin{array}{l}\text { Bagian } \\
\text { Keuangan }\end{array}$ & $\begin{array}{c}\text { Karyawan } \\
\text { Tetap }\end{array}$ & $\begin{array}{l}\text { - Mampu membuat laporan } \\
\text { keuangan. } \\
\text { - Mampu melakukan pencatatan } \\
\text { - } \text { dengan baik } \\
\text { - } \text { pemahamiatatan keuangann } \\
\text { - Pekerja keras. } \\
\text { - Mampu bekerja dalam tim. } \\
\text { - Memiliki kesungguhan dalam } \\
\text { bekerja }\end{array}$ & 1 \\
\hline 4. & Buruh & $\begin{array}{c}\text { Karyawan } \\
\text { Tidak } \\
\text { Tetap }\end{array}$ & $\begin{array}{l}\text { - Pekerja keras. } \\
\text { - Memiliki kesungguhan dalam } \\
\text { bekerja } \\
\text { - Memahami arti penting kualitas. }\end{array}$ & 12 \\
\hline
\end{tabular}

Jumlah tenaga kerja di perusahaan tersebut berjumlah 15 orang dan terbagi dalam dua bagian, yaitu tenaga kerja tetap (bagian keuangan, produksi dan pemasaran) sebanyak 3 orang dan tenaga kerja tidak tetap/borongan pada bagian produksi (bagian penjemuran, penggilingan, penyortiran dan pengemasan) 12 orang. Sumber daya manusia yang dimanfaatkan di bagian produksi sebanyak 12 orang yang terbagi atas bagian penjemuran 4 orang, bagian penggilingan 4 orang, serta penyortiran dan pengemasan sebanyak 4 orang.

\section{Proses Penggilingan Gabah}

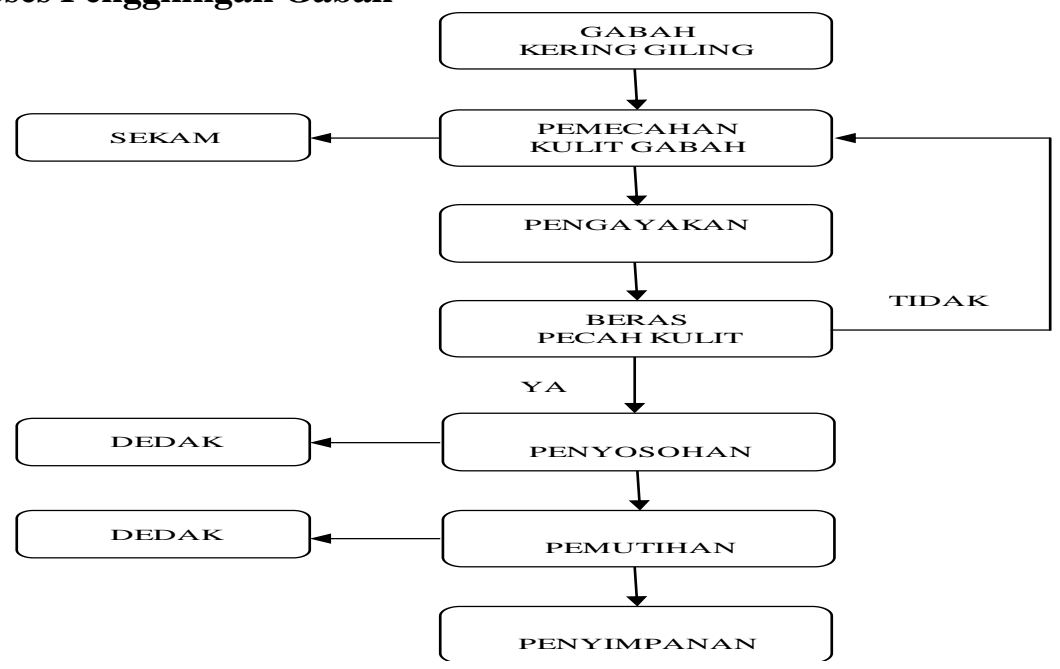

Gambar 3. Proses Penggilingan Gabah/ Padi 
Tabel 2. Spesifikasi Mutu Beras

\begin{tabular}{|c|l|c|c|c|c|c|c|}
\hline No & \multicolumn{1}{|c|}{ Komponen } & Satuan & $\begin{array}{c}\text { Mutu } \\
\text { I }\end{array}$ & $\begin{array}{c}\text { Mutu } \\
\text { II }\end{array}$ & $\begin{array}{c}\text { Mutu } \\
\text { III }\end{array}$ & $\begin{array}{c}\text { Mutu } \\
\text { IV }\end{array}$ & $\begin{array}{c}\text { Mutu } \\
\text { V }\end{array}$ \\
\hline 1 & Derajat Sosoh (min) & $\%$ & 100 & 100 & 95 & 95 & 95 \\
\hline 2 & Kadar Air (maks) & $\%$ & 14 & 14 & 14 & 14 & 15 \\
\hline 3 & Butir Kepala (min) & $\%$ & 95 & 89 & 78 & 73 & 60 \\
\hline 4 & Butir Patah (maks) & $\%$ & 5 & 10 & 20 & 25 & 35 \\
\hline 5 & Butir Menir (maks) & $\%$ & 0 & 1 & 2 & 2 & 5 \\
\hline 6 & Butir Merah (maks) & $\%$ & 0 & 1 & 2 & 3 & 3 \\
\hline 7 & $\begin{array}{l}\text { Butir Kuning/Rusak } \\
\text { (maks) }\end{array}$ & $\%$ & 0 & 1 & 2 & 3 & 5 \\
\hline 8 & Benda Asing (maks) & $\%$ & 0 & 0,02 & 0,02 & 0,05 & 0,20 \\
\hline 9 & Butir Gabah (maks) & $\begin{array}{c}\text { butir /100 } \\
\text { gram }\end{array}$ & 0 & 1 & 1 & 2 & 3 \\
\hline
\end{tabular}

\section{Aspek Pasar}

Sampai saat ini, jumlah penjualan beras perusahaan penggilingan padi PD. Ancol Jaya selalu meningkat dibanding periode sebelumnya. Berikut data penjualan beras perusahaan penggilingan padi PD. Ancol Jaya periode tahun 2011-2012:

Tabel 3. Jumlah Penjualan Beras Penggilingan Padi PD. Ancol Jaya

\begin{tabular}{|c|c|c|c|c|c|c|c|c|c|c|c|c|c|c|}
\hline \multirow{2}{*}{ NO } & \multirow{2}{*}{ TAHUN } & \multicolumn{10}{|c|}{ BULAN } & \multirow{2}{*}{ TOTAL } \\
\cline { 2 - 16 } & 1 & 2 & 3 & 4 & 5 & 6 & 7 & 8 & 9 & 10 & 11 & 12 & \\
\hline 1 & 2011 & 16.270 & 11.000 & 14.600 & 17.600 & 16.200 & 18.260 & 22.280 & 17.745 & 16.600 & 18.080 & 19.265 & 17.950 & 205.859 \\
\hline 2 & 2012 & 18.400 & 16.400 & 15.780 & 17.900 & 18.200 & 20.120 & 22.600 & 20.400 & 19.860 & 19.020 & 20.650 & 19.460 & 228.790 \\
\hline
\end{tabular}

Sumber: Data perusahaan yang telah diolah.

Besarnya kebutuhan beras untuk daerah Kabupaten Cianjur saja sebanyak 2.171.281 kapita, sedangkan produksi beras PD. Ancol Jaya hanya sebesar $228.790 \mathrm{Kg}$ pertahun. Itu artinya, produksi beras PD. Ancol Jaya hanya mampu memenuhi kebutuhan beras sekitar $0,10 \%$ pertahun (102 Kg beras/ kapita/ tahun) untuk wiayah Kabupaten Cianjur. Beberapa perusahaan yang dapat dijadikan sebagai pesaing bagi perusahaan penggilingan padi PD. Ancol Jaya antara lain perusahaan penggilingan padi PD. Sindang Asih, PD. Top King, PD. Teguh, PD. SDR yang semuanya berada di wilayah Kecamatan Karangtengah.

Beras yang diproduksi dikemas dengan berbagai macam ukuran, mulai dari kemasan $5 \mathrm{Kg}, 10 \mathrm{Kg}, 15 \mathrm{Kg}, 18 \mathrm{Kg}, 20 \mathrm{Kg}, 25 \mathrm{Kg}$, dan $50 \mathrm{Kg}$. Adanya pilihan produk berdasarkan jenis ukuran tersebut membuat konsumen bisa memilih produk yang berbeda sesuai keinginan dan kebutuhannya. Adapun harga beras serta dedak dan sekam sebagai hasil dari proses penggilingan padi dapat dilihat dari tabel berikut. 
Tabel 4. Daftar Harga Beras, Dedak dan Sekam Desember 2012

\begin{tabular}{|c|c|c|c|c|}
\hline NO & PRODUK & $\begin{array}{c}\text { KEMASAN } \\
\text { KG }\end{array}$ & $\begin{array}{r}\text { HAI } \\
\text { I }\end{array}$ & $\begin{array}{l}\text { JUAL } \\
\text { KG }\end{array}$ \\
\hline 1 & \multirow{7}{*}{ BERAS } & 5 & $\mathbf{R p}$ & 8,500 \\
\hline 2 & & 10 & $R_{p}$ & 8,500 \\
\hline 3 & & 15 & $\mathbf{R p}$ & 8,500 \\
\hline 4 & & 18 & $\mathbf{R p}$ & 8,500 \\
\hline 5 & & 20 & $\mathbf{R p}$ & 8,500 \\
\hline 6 & & 25 & $\mathbf{R p}_{\mathbf{p}}$ & 8,500 \\
\hline 7 & & 50 & $R_{p}$ & 8,500 \\
\hline 8 & DEDAK & 50 & $R_{p}$ & 1,400 \\
\hline 9 & SEKAM & 50 & $\mathbf{R p}$ & 250 \\
\hline
\end{tabular}

Sumber: Data Perusahaan Penggilingan Padi PD. Ancol Jaya Tahun 2012

Selain beras, dari proses penggilingan padi menghasilkan beberapa produk diantaranya dedak (kulit ari padi), sekam (kulit padi) serta menir (beras patahan). Dari hasil penggilingan padi sebanyak $100 \mathrm{Kg}$ gabah/ padi kering giling dapat menghasilkan beras sebanyak $65 \mathrm{Kg}(65 \%)$, Dedak $12 \mathrm{Kg}$ (12\%), Sekam $25 \mathrm{Kg}(25 \%)$. Sedangkan untuk pemasaran diluar kota Cianjur, perusahaan mempunyai agen yang mewakili wilayah pemasarannya. Distribusi pemasaran perusahaan penggilingan padi PD. Ancol Jaya dapat dilihat dalam gambar berikut:

$$
\text { SKEMA I SKEMA II }
$$
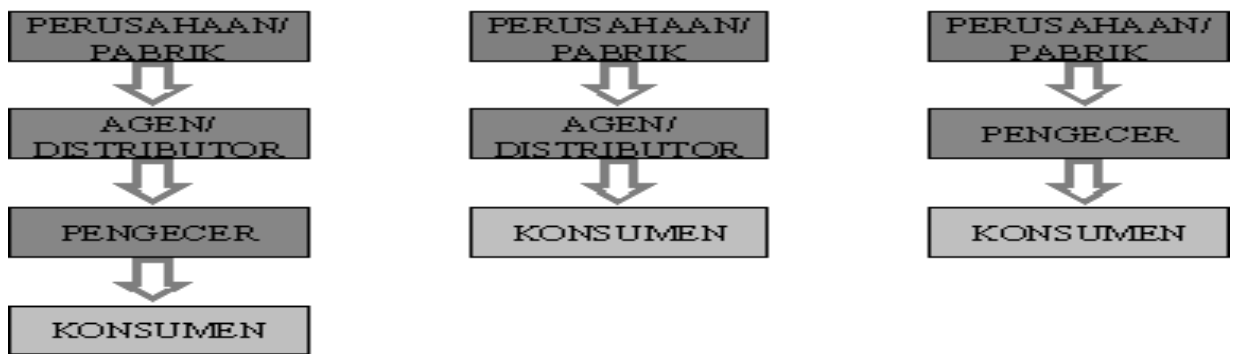

Gambar 4. Distribusi Pemasaran Penggilingan padi PD. Ancol Jaya

\section{Layout Perusahaan}

Layout pada sebuah usaha adalah proses penataan keseluruhan sumber daya yang dimiliki oleh perusahaan guna mencapai keseimbangan kegiatan operasi secara efisien. Berikut gambar layout perusahaan PD.Ancol Jaya.

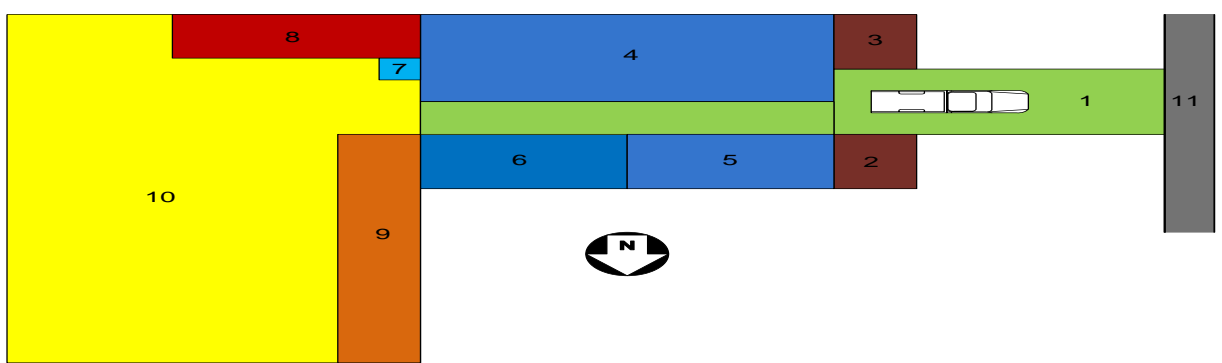

Gambar 5 Layout perusahaan penggilingan PD.Ancol Jaya.

Keterangan gambar:

1) Jalan masuk perusahaaan

7) Bak penampungan air

2) Kantor perusahaan

8) Tempat limbah (sekam)

3) Tempat istirahat \& mushola karyawan

9) Tempat penyimpanan bahan baku

4) Ruang produksi

10) Tempat penjemuran

5) Ruang penyortiran dan pengemasan

11) Jalan umum

6) Tempat penyimpanan bahan baku 
Tabel 5. Rencana Produksi Penggilingan Padi PD. Ancol Jaya

\begin{tabular}{|c|c|c|c|c|c|c|c|c|}
\hline \multirow{2}{*}{ NO } & \multirow{2}{*}{ TAHUN } & \multirow{2}{*}{$\begin{array}{c}\text { PRODUKSI BERAS } \\
(\mathrm{KG})\end{array}$} & \multicolumn{2}{|c|}{ KENAIKAN $10 \%$} & \multirow{2}{*}{ TAHUN } & \multicolumn{2}{|c|}{ KENAIKAN 25\% } & \multirow{2}{*}{ TOTAL } \\
\hline & & & IR 64 & AROMATIK & & IR 64 & AROMATIK & \\
\hline 1 & 2011 & 205.859 & - & - & - & - & - & - \\
\hline 2 & 2012 & 228.790 & - & - & - & - & - & - \\
\hline 3 & 2013 & 251.669 & 188.752 & 62.917 & 2013 & 285.988 & 96.796 & 382.783 \\
\hline 4 & 2014 & 276.836 & 207.627 & 69.209 & 2014 & 357.484 & 106.475 & 463.960 \\
\hline 5 & 2015 & 304.520 & 228.390 & 76.130 & 2015 & 446.855 & 117.123 & 563.979 \\
\hline 6 & 2016 & 334.970 & 251.228 & 83.743 & 2016 & 558.569 & 128.835 & 687.404 \\
\hline 7 & 2017 & 368.469 & 276.352 & 92.117 & 2017 & 698.212 & 141.719 & 839.931 \\
\hline \multicolumn{2}{|c|}{ TOTAL } & 1.536 .464 & 1.152 .348 & 384.116 & & 2.347 .108 & 590.948 & 2.938 .056 \\
\hline
\end{tabular}

\section{Aspek Finansial}

\section{Proyeksi Arus Kas (Cashflow)}

Tabel 6. Jumlah Produksi kondisi normal (kenaikan produksi 10\% per tahun)

\begin{tabular}{|c|c|c|c|c|c|c|c|c|c|}
\hline \multirow{2}{*}{ NO } & \multicolumn{2}{|c|}{ BERAS } & \multirow{2}{*}{ TOTAL } & \multicolumn{2}{|c|}{ DEDAK } & \multirow{2}{*}{ TOTAL } & \multicolumn{2}{|c|}{ SEKAM } & \multirow{2}{*}{ TOTAL } \\
\hline & IR 64 & AROMATIK & & IR 64 & AROMATIK & & IR 64 & AROMATIK & \\
\hline 1 & 188.752 & 62.917 & 251.669 & 34.846 & 11.615 & 46.462 & 72.597 & 24.199 & 96.796 \\
\hline 2 & 207.627 & 69.209 & 276.836 & 38.331 & 12.777 & 51.108 & 79.857 & 26.619 & 106.475 \\
\hline 3 & 228.390 & 76.130 & 304.520 & 42.164 & 14.055 & 56.219 & 87.842 & 29.281 & 117.123 \\
\hline 4 & 251.228 & 83.743 & 334.970 & 46.380 & 15.460 & 61.841 & 96.626 & 32.209 & 128.835 \\
\hline 5 & 276.352 & 92.117 & 368.469 & 51.019 & 17.006 & 68.025 & 106.289 & 35.430 & 141.719 \\
\hline & 1.152 .348 & 384.116 & 1.536 .464 & 212.741 & 70.914 & 283.655 & 443.211 & 147.737 & 590.948 \\
\hline
\end{tabular}

Tabel 7. Jumlah Produksi kondisi optimis (kenaikan produksi $25 \%$ per tahun)

\begin{tabular}{|c|c|c|c|c|c|c|c|c|c|}
\hline \multirow{2}{*}{ NO } & \multicolumn{2}{|c|}{ BERAS } & \multirow{2}{*}{ TOTAL } & \multicolumn{2}{|c|}{ DEDAK } & \multirow{2}{*}{ TOTAL } & \multicolumn{2}{|c|}{ SEKAM } & \multirow{2}{*}{ TOTAL } \\
\hline & IR 64 & AROMATIK & & IR 64 & AROMATIK & & IR 64 & AROMATIK & \\
\hline 1 & 214.491 & 71.497 & 285.988 & 39.598 & 13.199 & 52.798 & 82.496 & 27.499 & 109.995 \\
\hline 2 & 268.113 & 89.371 & 357.484 & 49.498 & 16.499 & 65.997 & 103.120 & 34.373 & 137.494 \\
\hline 3 & 335.142 & 111.714 & 446.855 & 61.872 & 20.624 & 82.496 & 128.901 & 42.967 & 171.867 \\
\hline 4 & 418.927 & 139.642 & 558.569 & 77.340 & 25.780 & 103.120 & 161.126 & 53.709 & 214.834 \\
\hline 5 & 523.659 & 174.553 & 698.212 & 96.675 & 32.225 & 128.901 & 201.407 & 67.136 & 268.543 \\
\hline & 1.760 .331 & 586.777 & 2.347 .108 & 324.984 & 108.328 & 433.312 & 677.050 & 225.683 & 902.734 \\
\hline
\end{tabular}

Tabel 8. Total Penjualan Kondisi Normal

(Kenaikan harga $5 \%$ dan kenaikan produksi $10 \%$ per tahun)

\begin{tabular}{|c|c|c|c|c|c|c|c|c|c|c|}
\hline \multirow{2}{*}{ PRODUK } & \multicolumn{10}{|c|}{ HARGA PADA TAHUN- } \\
\hline & \multicolumn{2}{|r|}{1} & \multicolumn{2}{|r|}{2} & \multicolumn{2}{|r|}{3} & \multicolumn{2}{|r|}{4} & \multicolumn{2}{|r|}{5} \\
\hline BERAS & $\mathrm{Rp}$ & $8.500,0$ & $\mathrm{Rp}$ & $8.925,0$ & $\mathrm{Rp}$ & $9.371,3$ & $\mathrm{Rp}$ & $9.839,8$ & $\mathrm{Rp}$ & $10.331,8$ \\
\hline DEDAK & $\mathrm{Rp}$ & $1.400,0$ & $\mathrm{Rp}$ & $1.470,0$ & $\mathrm{Rp}$ & $1.543,5$ & $\mathrm{Rp}$ & $1.620,7$ & $\mathrm{Rp}$ & $1.701,7$ \\
\hline SEKAM & $\mathrm{Rp}$ & 250,0 & $\mathrm{Rp}$ & 262,5 & $\mathrm{Rp}$ & 275,6 & $\mathrm{Rp}$ & 289,4 & $\mathrm{Rp}$ & 303,9 \\
\hline PRODUK & \multicolumn{10}{|c|}{ INFLOW/ PENERIMAAN } \\
\hline BERAS & \multicolumn{2}{|c|}{ Rp 2.139.186.500 } & \multicolumn{2}{|c|}{$\operatorname{Rp} 2.470 .761 .300$} & \multicolumn{2}{|c|}{ Rp 2.853.733.050 } & \multicolumn{2}{|c|}{ Rp 3.296.041.993 } & \multicolumn{2}{|c|}{ Rp 3.806.949.166 } \\
\hline DEDAK & $\mathrm{Rp}$ & 65.046 .757 & $\mathrm{Rp}$ & 75.129 .031 & $\mathrm{Rp}$ & 86.774 .145 & & 100.223 .539 & $\mathrm{Rp}$ & 115.758 .816 \\
\hline SEKAM & $\mathrm{Rp}$ & 24.198 .942 & $\mathrm{Rp}$ & 27.949 .788 & $\mathrm{Rp}$ & 32.282 .048 & & 37.285 .543 & $\mathrm{Rp}$ & 43.065 .036 \\
\hline TOTAL & & 228.432.199 & $\mathrm{Rp}$ & 573.840 .120 & $\mathrm{Rp} 2$ & 972.789 .243 & & 3.433 .551 .075 & Rp 3 & .965 .773 .018 \\
\hline
\end{tabular}


Tabel 9. Total Penjualan Kondisi Optimis

(Kenaikan harga $5 \%$ dan kenaikan produksi $25 \%$ per tahun)

\begin{tabular}{|c|c|c|c|c|c|c|c|c|c|c|}
\hline \multirow{2}{*}{ PRODUK } & \multicolumn{10}{|c|}{ HARGA PADA TAHUN- } \\
\hline & \multicolumn{2}{|r|}{1} & \multicolumn{2}{|r|}{2} & \multicolumn{2}{|r|}{3} & \multicolumn{2}{|r|}{4} & \multicolumn{2}{|r|}{5} \\
\hline BERAS & $\mathrm{Rp}$ & $8.500,0$ & $\mathrm{Rp}$ & $8.925,0$ & $\mathrm{Rp}$ & $9.371,3$ & $\mathrm{Rp}$ & $9.839,8$ & $\mathrm{Rp}$ & $10.331,8$ \\
\hline DEDAK & $\mathrm{Rp}$ & $1.400,0$ & $\mathrm{Rp}$ & $1.470,0$ & $\mathrm{Rp}$ & $1.543,5$ & $\mathrm{Rp}$ & $1.620,7$ & $\mathrm{Rp}$ & $1.701,7$ \\
\hline SEKAM & $\mathrm{Rp}$ & 250,0 & $\mathrm{Rp}$ & 262,5 & $\mathrm{Rp}$ & 275,6 & $\mathrm{Rp}$ & 289,4 & $\mathrm{Rp}$ & 303,9 \\
\hline PRODUK & \multicolumn{10}{|c|}{ INFLOW/ PENERIMAAN } \\
\hline BERAS & \multicolumn{2}{|c|}{ Rp 2.430.893.750 } & \multicolumn{2}{|c|}{ Rp 3.190.548.047 } & \multicolumn{2}{|c|}{ Rp 4.187.594.312 } & \multicolumn{2}{|c|}{ Rp 5.496.217.534 } & \multicolumn{2}{|c|}{$\mathrm{Rp} 7.213 .785 .513$} \\
\hline DEDAK & $\mathrm{Rp}$ & 73.916 .769 & $\mathrm{Rp}$ & 97.015 .760 & $\mathrm{Rp}$ & 127.333 .184 & & 167.124 .805 & $\mathrm{Rp}$ & 219.351 .306 \\
\hline SEKAM & $\mathrm{Rp}$ & 27.498 .798 & & 36.092 .172 & $\mathrm{Rp}$ & 47.370 .976 & & 62.174 .406 & $\mathrm{Rp}$ & 81.603 .909 \\
\hline TOTAL & $\mathrm{Rp} 2$. & 532.309 .317 & $\mathrm{Rp}$ & 323.655 .979 & Rp 4 & .362 .298 .472 & & 5.725 .516 .745 & Rp 7 & .514 .740 .728 \\
\hline
\end{tabular}

Tabel 10. Investasi Usaha Penggilingan Padi PD. Ancol Jaya Kondisi Normal (Kenaikan

\begin{tabular}{|c|c|c|c|c|c|c|c|c|c|c|c|c|c|}
\hline \multirow{2}{*}{ No } & \multirow{2}{*}{ Jenis Aktiva } & \multirow{2}{*}{ Merek } & \multirow{2}{*}{ Sepsifikasi } & \multirow{2}{*}{$\begin{array}{c}\text { Umur } \\
\text { Ekonomis } \\
\text { (Tahun) }\end{array}$} & \multirow{2}{*}{ Satuan } & \multicolumn{2}{|c|}{ Harga Beli } & \multicolumn{2}{|c|}{ Harga Perolehan } & \multicolumn{2}{|c|}{ Nilai Sisa } & \multicolumn{2}{|c|}{ Depresiasi } \\
\hline & & & & & & Harga per Satuan & Total & Harga per Satuan & Total & Per Satuan & Total & Per Satuan & Total \\
\hline 1 & Tanah (1900 m2) & & & & 1 unit & Rp 30.000 .000 & Rp 30.000.000 & Rp 293.120.884 & Rp 293.120.884 & Rp 293.120.884 & Rp 293.120.884 & - & . \\
\hline 2 & Bangunan Pabrik & & & 10 & 1 unit & $\operatorname{Rp} 50.000 .000$ & Rp 50.000.000 & Rp 121.322.412 & Rp 121.322.412 & Rp 48.528 .965 & Rp 48.528 .965 & Rp 14.558.689 & Rp 14.558.689 \\
\hline 4 & Mobil & Mitsubishi & T120ss & 5 & 1 unit & $\operatorname{Rp} 75.000 .000$ & Rp 75.000.000 & $\operatorname{Rp} 75.000 .000$ & $\operatorname{Rp} 75.000 .000$ & $\operatorname{Rp} 30.000 .000$ & $\operatorname{Rp} 30.000 .000$ & Rp 9.000 .000 & $\operatorname{Rp} 9.000 .000$ \\
\hline 5 & Komputer & HP Pavilion 20 & b100L & 5 & 1 Set & $\operatorname{Rp} \quad 5.000 .000$ & $\operatorname{Rp} 5.000 .000$ & Rp $\quad 5.000 .000$ & $\operatorname{Rp} \quad 5.000 .000$ & Rp & $R p$ & $\operatorname{Rp} 1.000 .000$ & $\operatorname{Rp} 1.000 .000$ \\
\hline 6 & Printer & Epson & L110 & 5 & 1 set & $\operatorname{Rp} \quad 1.450 .000$ & $\operatorname{Rp} 1.450 .000$ & Rp 1.450 .000 & $\operatorname{Rp} \quad 1.450 .000$ & $R p$ & Rp & Rp $\quad 290.000$ & $\operatorname{Rp} \quad 290.000$ \\
\hline 7 & Telepon & PANASONIC & KX-TS505MXH & 5 & 1 set & $\begin{array}{ll}\mathrm{Rp} & 178.000 \\
\end{array}$ & $\begin{array}{ll}\operatorname{Rp} & 178.000 \\
\end{array}$ & 178.000 & Rp $\quad 178.000$ & $\mathrm{Rp}$ & $R p$ & $\operatorname{Rp} \quad 35.600$ & $\begin{array}{ll}\operatorname{Rp} \quad 35.600 \\
\end{array}$ \\
\hline \multirow[t]{2}{*}{8} & Kipas Angin & Cosmos & WADESTA & 5 & 1 buah & 300.000 & $\operatorname{Rp} \quad 300.000$ & 300.000 & Rp $\quad 300.000$ & Rp & Rp & $\operatorname{Rp} \quad 60.000$ & Rp $\quad 60.000$ \\
\hline & FURNITURE & & & & & & & & & & & & \\
\hline 9 & Ruang Kantor & & & 5 & 4 set & $\begin{array}{ll}\operatorname{Rp} & 750.000 \\
\end{array}$ & $\operatorname{Rp} 3.000 .000$ & $\begin{array}{ll}\operatorname{Rp} & 750.000 \\
\end{array}$ & $\operatorname{Rp} \quad 3.000 .000$ & 75.000 & $\begin{array}{ll}\operatorname{Rp} & 300.000 \\
\end{array}$ & Rp 135.000 & Rp $\quad 540.000$ \\
\hline 10 & Instalasi listrik & & & 5 & 1 set & $\operatorname{Rp} \quad 5.000 .000$ & $\operatorname{Rp} 5.000 .000$ & $\operatorname{Rp} \quad 5.000 .000$ & $\operatorname{Rp} \quad 5.000 .000$ & Rp & $R p$ & $\operatorname{Rp} 1.000 .000$ & $\operatorname{Rp} 1.000 .000$ \\
\hline \multirow[t]{2}{*}{11} & Instalasi Air & & & 5 & 1 set & $\operatorname{Rp} \quad 4.000 .000$ & Rp 4.000.000 & $\operatorname{Rp} \quad 4.000 .000$ & $\operatorname{Rp} \quad 4.000 .000$ & $\mathrm{Rp}$ & Rp & Rp $\quad 800.000$ & Rp $\quad 800.000$ \\
\hline & Mesin Fabrikasi & & & & & & & & & & & & \\
\hline 12 & Penggerak diesel & Mitsubishi & D14 & 5 & 1 unit & $\operatorname{Rp} 20.000 .000$ & Rp 20.000.000 & $\operatorname{Rp} 20.000 .000$ & Rp 20.000 .000 & Rp $\quad 8.000 .000$ & Rp $\quad 8.000 .000$ & Rp 2.400 .000 & $\operatorname{Rp} 2.400 .000$ \\
\hline 13 & Pengupas kulit gabah & YANMAR & LM-24 & 5 & 1 unit & $\begin{array}{ll}\operatorname{Rp} & 7.500 .000 \\
\end{array}$ & $\operatorname{Rp} 7.500 .000$ & Rp $\quad 7.500 .000$ & $\begin{array}{ll}\operatorname{Rp} & 7.500 .000 \\
\end{array}$ & $\operatorname{Rp} \quad 750.000$ & $\operatorname{Rp} \quad 750.000$ & Rp 1.350 .000 & $\operatorname{Rp} 1.350 .000$ \\
\hline 14 & Penyosoh (polisher) & $\mathrm{ICH}$ & $\mathrm{N}-70$ & 5 & 1 unit & $\begin{array}{ll}\operatorname{Rp} \quad 5.000 .000 \\
\end{array}$ & Rp 5.000.000 & $\operatorname{Rp} \quad 5.000 .000$ & $\operatorname{Rp} \quad 5.000 .000$ & \begin{tabular}{ll|}
$\operatorname{Rp}$ & 500.000 \\
\end{tabular} & $\operatorname{Rp} \quad 500.000$ & Rp $\quad 900.000$ & Rp $\quad 900.000$ \\
\hline 15 & Pemutih (polisher) & ICHI & $\mathrm{N}-70$ & 5 & 1 unit & Rp $\quad 5.000 .000$ & Rp 5.000.000 & Rp $\quad 5.000 .000$ & Rp $\quad 5.000 .000$ & \begin{tabular}{ll|}
$\operatorname{Rp}$ & 500.000 \\
\end{tabular} & Rp $\quad 500.000$ & Rp $\quad 900.000$ & Rp $\quad 900.000$ \\
\hline 16 & Instalasi Mesin & & & 5 & 4 set & $\operatorname{Rp} \quad 4.000 .000$ & $\operatorname{Rp} 16.000 .000$ & $\operatorname{Rp} \quad 4.000 .000$ & Rp 16.000 .000 & $R p$ & $R p$ & $\operatorname{Rp} \quad 800.000$ & Rp 3.200 .000 \\
\hline 17 . & Jahit Karung & Newlong & NP.7A & 5 & 1 buah & $\operatorname{Rp} \quad 1.000 .000$ & $\operatorname{Rp} 1.000 .000$ & Rp $\quad 1.000 .000$ & $\operatorname{Rp} \quad 1.000 .000$ & $\begin{array}{|ll|}\operatorname{Rp} & 100.000 \\
\end{array}$ & $\begin{array}{ll}\operatorname{Rp} & 100.000 \\
\end{array}$ & Rp $\quad 180.000$ & $\begin{array}{ll}\operatorname{Rp} \quad 180.000 \\
\end{array}$ \\
\hline 18 & Alat Tester Kadar Air & & & 5 & 1 buah & $\begin{array}{ll}\operatorname{Rp} & 1.500 .000 \\
\end{array}$ & $\operatorname{Rp} 1.500 .000$ & $\operatorname{Rp} \quad 1.500 .000$ & $\operatorname{Rp} 1.500 .000$ & $\begin{array}{ll}\operatorname{Rp} & 150.000 \\
\end{array}$ & $\begin{array}{ll}\operatorname{Rp} & 150.000 \\
\end{array}$ & $\operatorname{Rp} \quad 270.000$ & Rp $\quad 270.000$ \\
\hline \multirow[t]{2}{*}{19} & Timbangan & Cahaya Adil & & 5 & 2 buah & $\begin{array}{|ll|}\operatorname{Rp} & 1.500 .000 \\
\end{array}$ & Rp 3.000.000 & $\operatorname{Rp} \quad 1.500 .000$ & $\operatorname{Rp} \quad 3.000 .000$ & \begin{tabular}{ll|}
$\operatorname{Rp}$ & 150.000 \\
\end{tabular} & $\operatorname{Rp} \quad 300.000$ & $\operatorname{Rp} \quad 270.000$ & Rp $\quad 540.000$ \\
\hline & & & & & & & Total & & Rp 567.371.296 & Rp 381.874.849 & Rp 382.249.849 & Rp33.949.289 & Rp37.024.289 \\
\hline
\end{tabular}


Tabel 11. Investasi Usaha Penggilingan Padi PD. Ancol Jaya Kondisi Optimis (Kenaikan Produksi $25 \%$ per tahun)

\begin{tabular}{|c|c|c|c|c|c|c|c|c|c|c|c|c|c|}
\hline \multirow{2}{*}{ № } & \multirow{2}{*}{ Jenis Aktiva } & \multirow{2}{*}{ Merek } & \multirow{2}{*}{ Sepsifikasi } & \multirow{2}{*}{$\begin{array}{c}\text { Umur } \\
\text { Ekonomis } \\
\text { (Tahun) }\end{array}$} & \multirow{2}{*}{ Satuan } & \multicolumn{2}{|c|}{ Harga Beli } & \multicolumn{2}{|c|}{ Harga Perolehan Saat Ini } & \multicolumn{2}{|c|}{ Nillai Sisa } & \multicolumn{2}{|c|}{ Depresiasi } \\
\hline & & & & & & Per Satuan & Total & Per Satuan & Total & Per Satuan & Total & Per Satuan & Total \\
\hline 1 & Tanah (1900 m2) & & & & 1 unit & $\operatorname{Rp} 30.000 .000$ & $\operatorname{Rp} 30.000 .000$ & Rp 293.120.884 & Rp 293.120.884 & Rp 293.120.884 & $\operatorname{Rp} 293.120 .884$ & $\operatorname{Rp}$ & $\mathrm{Rp}$ \\
\hline 2 & Bangunan Pabrik & & & 10 & 1 unit & Rp 50.000.000 & Rp 50.000.000 & Rp 121.322.412 & Rp 121.322.412 & Rp 48.528.965 $\mathrm{B}$ & Rp 48.528.965 & Rp 14.558.689 & Rp 14.558 .689 \\
\hline 41 & Mobil & Mitsubishi & T120ss & 5 & 1 unit & $\operatorname{Rp} 75.000 .000$ & $\operatorname{Rp} 75.000 .000$ & $\operatorname{Rp} 75.000 .000$ & Rp 75.000.000 & $\operatorname{Rp} 30.000 .000$ & Rp 30.000.000 & $\operatorname{Rp} \quad 9.000 .000$ & $\operatorname{Rp} 9.000 .000$ \\
\hline 5 & Komputer & HP Pavilion 20 & B100I & 5 & 1 Set & $\operatorname{Rp} \quad 5.000 .000$ & $\operatorname{Rp} 5.000 .000$ & $\operatorname{Rp} \quad 5.000 .000$ & $\operatorname{Rp} \quad 5.000 .000$ & $\operatorname{Rp}$ & $\operatorname{Rp}$ & $\begin{array}{ll}\operatorname{Rp} & 1.000 .000 \\
\end{array}$ & $\operatorname{Rp} \quad 1.000 .000$ \\
\hline $6 P$ & Printer & Epson & $\mathrm{L} 110$ & 5 & 1 set & $\operatorname{Rp} \quad 1.450 .000$ & $\operatorname{Rp} 1.450 .000$ & Rp 1.450 .000 & $\operatorname{Rp} \quad 1.450 .000$ & $\operatorname{Rp}$ & $\operatorname{Rp}$ & $\operatorname{Rp} \quad 290.000$ & Rp $\quad 290.000$ \\
\hline 7 & Telepon & PANASONIC & KX-TS505MXH & 5 & 1 set & $\begin{array}{ll}\operatorname{Rp} & 178.000 \\
\end{array}$ & $\begin{array}{|ll|}\operatorname{Rp} & 178.000 \\
\end{array}$ & $\begin{array}{ll}\operatorname{Rp} & 178.000 \\
\end{array}$ & $\begin{array}{|ll|}\operatorname{Rp} & 178.000 \\
\end{array}$ & Rp & $R p$ & 35.600 & 35.600 \\
\hline 8 & Kipas Angin & Cosmos & WADESTA & 5 & 1 buah & $\operatorname{Rp} \quad 300.000$ & Rp 300.000 & Rp $\quad 300.000$ & Rp $\quad 300.000$ & $\operatorname{Rp}$ & $R p$ & 60.000 & 60.000 \\
\hline & FURNITURE & & & & & & & & & & Rp & & $\mathrm{Rp}$ \\
\hline & Ruang Kantor & & & 5 & 4 set & $\operatorname{Rp} \quad 750.000$ & $\operatorname{Rp} 3.000 .000$ & $\operatorname{Rp} \quad 750.000$ & $\operatorname{Rp} \quad 3.000 .000$ & $75.000 \mathrm{~A}$ & Rp $\quad 300.000$ & 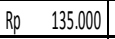 & Rp $\quad 540.000$ \\
\hline 10 & Instalasi listrik & & & 5 & 1 set & Rp $\quad 5.000 .000$ & Rp 5.000.000 & Rp $\quad 5.000 .000$ & $\operatorname{Rp} \quad 5.000 .000$ & Rp & $\operatorname{Rp}$ & Rp 1.000 .000 & Rp 1.000 .000 \\
\hline & Instalasi Air & & & 5 & 1 set & Rp $\quad 4.000 .000$ & Rp 4.000 .000 & Rp 4.000 .000 & $\operatorname{Rp} \quad 4.000 .000$ & Rp & $\operatorname{Rp}$ & Rp $\quad 800.000$ & Rp $\quad 800.000$ \\
\hline & Mesin Fabrikasi & & & & & & & & & & $\operatorname{Rp}$ & & $\operatorname{Rp}$ \\
\hline & Penggerak diesel & Mitsubishi & 016 & 5 & 1 unit & $\operatorname{Rp} 30.000 .000$ & $\operatorname{Rp} 30.000 .000$ & $\operatorname{Rp} 30.000 .000$ & Rp 30.000.000 & $\operatorname{Rpp} 12.000 .000$ & Rp 12.000.000 & $\operatorname{Rp} \quad 3.600 .000$ & Rp 3.600 .000 \\
\hline & Pengupas Kulitgabah & YANMAR & LM-24 & 5 & 2 unit & $\operatorname{Rp} 7.500 .000$ & $\operatorname{Rp} 15.000 .000$ & $\operatorname{Rp} 7.500 .000$ & Rp 15.000.000 & $\operatorname{Rp} \quad 750.000$ & $\operatorname{Rp} \quad 1.500 .000$ & $\operatorname{Rp} \quad 1.350 .000$ & Rp 2.700 .000 \\
\hline & Penyosoh (polisher) & $\mathrm{ICH}$ & $\mathrm{N}-70$ & 5 & 1 unit & $\operatorname{Rp} \quad 5.000 .000$ & $\operatorname{Rp} 5.000 .000$ & $\operatorname{Rp} \quad 5.000 .000$ & $\operatorname{Rp} \quad 5.000 .000$ & $\operatorname{Rp} \quad 500.000$ R & Rp $\quad 500.000$ & Rp $\quad 900.000$ & Rp $\quad 900.000$ \\
\hline 15 & Pemutih (polisher) & $\mathrm{ICH}$ & $\mathrm{N}-70$ & 5 & 1 unit & $\operatorname{Rp} \quad 5.000 .000$ & $\operatorname{Rp} 5.000 .000$ & $\operatorname{Rp} \quad 5.000 .000$ & $\operatorname{Rp} \quad 5.000 .000$ & $\operatorname{Rp} \quad 500.000 \mathrm{~A}$ & Rp $\quad 500.000$ & Rp $\quad 900.000$ & Rp $\quad 900.000$ \\
\hline & Mesin Pengering Padi & & 4 TON & 5 & 1 unit & $\operatorname{Rp} 35.000 .000$ & $\operatorname{Rp} 35.000 .000$ & $\operatorname{Rp} 35.000 .000$ & Rp 35.000.000 & $\operatorname{Rpp} 14.000 .000$ & Rp 14.000.000 & $\operatorname{Rp} \quad 4.200 .000$ & Rp $\quad 4.200 .000$ \\
\hline & Instalasi Mesin & & & 5 & 4 set & $\operatorname{Rp} \quad 4,000.000$ & $\operatorname{Rp} 16.000 .000$ & Rp $\quad 4.000 .000$ & Rp 16.000.000 & $\operatorname{Rp}$ & $\operatorname{Rp}$ & $\begin{array}{ll}\text { Rp } & 800.000 \\
\end{array}$ & Rp $\quad 3.200 .000$ \\
\hline & Jahit Karung & Newlong & NP-7A & 5 & 1 buah & $\operatorname{Rp} \quad 1.000 .000$ & Rp 1.000 .000 & Rp 1.000 .000 & $\operatorname{Rp} \quad 1.000 .000$ & $\operatorname{Rp} \quad 100.000$ R & Rp $\quad 100.000$ & $\operatorname{Rp} \quad 180.000$ & Rp $\quad 180.000$ \\
\hline & Alat Tester Kadar Air & & & 5 & 1 set & Rp 1.500 .000 & Rp 1.500.000 & Rp 1.500 .000 & $\operatorname{Rp} \quad 1.500 .000$ & $\operatorname{Rp} \quad 150.000$ & Rp $\quad 150.000$ & Rp $\quad 270.000$ & Rp $\quad 270.000$ \\
\hline \multirow{2}{*}{\multicolumn{2}{|c|}{\begin{tabular}{l|l}
20 & Timbangan \\
\end{tabular}}} & Cahaya Adil & & 5 & 2 buah & $\operatorname{Rp} \quad 1.500 .000$ & Rp 3.000 .000 & Rp $\quad 1.500 .000$ & $\operatorname{Rp} \quad 3.000 .000$ & Rp $\quad 150.000$ & Rp $\quad 300.000$ & Rp $\quad 270.000$ & Rp $\quad 540.000$ \\
\hline & & & & & & & Total & & Rp 619.871.296 & $\operatorname{Rp} 399.874 .849$ & Rp 400.999.849 & $\operatorname{Rp} 39.349 .289$ & Rp 43.774.289 \\
\hline
\end{tabular}

\section{Analisis Kelayakan Investasi}

Dalam menganalisis kelayakan investasi pengembangan usaha penggilingan padi di perusahaan PD. Ancol Jaya digunakan kriteria investasi seperti Net Present Value (NPV), Internal Rate of Return (IRR), Net Benefit-Cost Ratio (B/C), dan Payback Periode (PP). Hasil analisis pada tabel berikut:

Tabel 12. Rekapitulasi Hasil Perhitungan Kriteria Investasi Kondisi Normal (Kenaikan Produksi 10\% per tahun)

\begin{tabular}{|c|c|c|}
\hline URAIAN & & NILAI \\
\hline Net Present Value (NPV) 13,5\% & $\mathrm{Rp}$ & $1.088 .835 .228,83$ \\
\hline Internal Rate of Return (IRR) & & $64 \%$ \\
\hline Net Benefit/Cost (B/C) & & 2,919 \\
\hline Pay Back Periode (tahun) & & 2,04 \\
\hline
\end{tabular}

Tabel 13. Rekapitulasi Hasil Perhitungan Kriteria Investasi Kondisi Optimis (Kenaikan Produksi $25 \%$ per tahun)

\begin{tabular}{|c|c|c|}
\hline URAIAN & & NILAI \\
\hline Net Present Value (NPV) $13,5 \%$ & $\mathrm{Rp}$ & $1.640 .304 .738,04$ \\
\hline Internal Rate of Return (IRR) & & $76 \%$ \\
\hline Net Benefit/Cost (B/C) & & 3,646 \\
\hline Pay Back Periode (tahun) & & 1,84 \\
\hline
\end{tabular}

Untuk lebih jelasnya, analisis kelayakan kriteria investasi dapat dilihat melalui perhitungan cashflow yang tertera pada Lampiran. 


\section{Net Present Value (NPV)}

Perhitungan Net Present Value (NPV) dilakukan untuk mengetahui nilai sekarang (Present Value) manfaat bersih yang diperoleh selama periode usaha. Pada perhitungan analisa kelayakan usaha dalam kondisi normal diperoleh nilai Net Present Value (NPV) sebesar Rp. 1.088.835.228,83 yang berarti usaha penggilingan padi di perusahaan PD. Ancol Jaya menghasilkan manfaat bersih sebesar Rp. 1.088.835.228,83 yang diperoleh selama umur usaha (5 tahun).

Sedangkan pada perhitungan analisa kelayakan usaha dalam kondisi optimis, diperoleh nilai Net Present Value (NPV) sebesar Rp. 1.604.304.738,04 yang berarti bahwa usaha penggilingan padi di perusahaan PD. Ancol Jaya akan menghasilkan manfaat bersih sebesar Rp. 1.604.304.738,04 yang diperoleh selama umur usaha ( 5 tahun) dalam kondisi optimis atau produksi beras mengalami kenaikan sebesar $25 \%$.

Dari uraian tersebut dapat diketahui usaha penggilingan padi di perusahaan PD. Ancol Jaya layak untuk dilaksanakan baik dalam kondisi normal maupun dalam kondisi optimis, karena dalam kedua analisa tersebut diperoleh nilai Net Present Value (NPV) lebih besar dari nol (NPV > 0).

\section{Net Benefit Cost Ratio (Net B/C)}

Net Benefit Cost Ratio (Net B/C) adalah rasio antara manfaat bersih yang bernilai positif dengan manfaat bersih yang bernilai negatif, artinya manfaat bersih yang menguntungkan bisnis yang dihasilkan setiap satuan kerugian dari usaha tersebut. Jika hasil nilai Net Benefit Cost Ratio (Net B/C) bernilai positif maka ketika perusahaan mengeluarkan sedikit biaya tambahan maka nilai manfaat tambahan yang diperolehnya akan lebih banyak (sebesar nilai $N e t \quad B / C$ yang dihasilkan). Pada perhitungan Net Benefit Cost Ratio (Net B/C) dalam analisis kriteria investasi diperoleh nilai $N e t$ B/C sebesar 2,919 dalam kondisi normal, serta 3,646 dalam kondisi optimis. Hal ini menunjukan bahwa setiap tambahan biaya sebesar Rp1,00 dapat menghasilkan tambahan manfaat bersih sebesar Rp. 2,919 pada kondisi normal serta RP. 3,646 pada kondisi optimis. Nilai Net Benefit Cost Ratio $(\mathrm{Net} \mathrm{B} / \mathrm{C})$ usaha penggilingan padi di perusahaan PD. Ancol Jaya ini lebih besar dari satu, sehingga usaha ini layak untuk dilaksanakan Net Benefit Cost Ratio (Net B/C > 1).

\section{Internal Rate of Return (IRR)}

Untuk mengetahui kelayakan suatu usaha melalui nilai Internal Rate of Return (IRR), maka tersebut harus dibandingkan dengan cost of capital. Nilai cost of capital yang digunakan sebesar 13,5\%. Dari hasil perhitungan kriteria kelayakan investasi usaha penggilingan padi di perusahaan PD. Ancol Jaya, dalam kondisi normal diperoleh nilai Internal Rate of Return (IRR) sebesar 64\%. sedangkan dalam kondisi optimis diperoleh nilai Internal Rate of Return (IRR) sebesar $76 \%$. Nilai tersebut mengartikan bahwa tingkat pengembalian usaha penggilingan padi di perusahaan PD. Ancol Jaya terhadap investasi yang ditanamkan sebesar $66 \%$ dalam kondisi normal serta $77 \%$ dalam kondisi optimis.

Nilai Internal Rate of Return (IRR) yang diperoleh pada kedua analisis dalam kriteria investasi ini memiliki nilai yang lebih besar dibandingkan dengan nilai cost of capital yang telah ditentukan yaitu sebesar 13,5\% (IRR>DR), sehingga usaha penggilingan padi di perusahaan PD. Ancol Jaya layak untuk dilaksanakan. Hal ini menunjukan bahwa usaha dengan proyeksi keadaan normal (kenaikan produksi $10 \%$ per tahun) serta dalam keadaan optimis (kenaikan produksi $25 \%$ per tahun) dengan melakukan penambahan teknologi masih layak untuk diusahakan terus dijalankan. 


\section{Payback Period (PP)}

Payback Period (PP) digunakan untuk melihat jangka waktu pengembalian modal. Payback Period usaha penggilingan padi di perusahaan PD. Ancol Jaya ini yakni selama 2,04 tahun pada kondisi normal serta 1,84 tahun dalam kondisi optimis. Nilai tersebut menunjukan bahwa seluruh biaya investasi dapat dikembalikan dalam jangka sekitar dua tahun lima belas hari dalam kondisi normal serta satu tahun sepuluh bulan tiga hari dalam kondisi optimis. Bila dibandingkan dengan umur usaha yakni selama 5 tahun, maka jangka waktu pengembalian modal usaha lebih cepat dibandingkan dengan umur usaha. Dengan demikian, usaha penggilingan padi di perusahaan PD. Ancol Jaya layak untuk dilaksanakan karena memiliki nilai Payback Period (PP) kurang dari umur usaha/investasi.

Dari nilai perhitungan berbagai kriteria kelayakan investasi dalam dua kondisi berbeda pada usaha penggilingan padi di perusahaan PD. Ancol Jaya dapat dikatakan layak untuk dijalankan, karena memiliki nilai Net Present Value (NPV) lebih dari nol (NPV >0), Net Benefit-Cost Ratio (B/C) lebih dari satu (Net B/C > 1), Internal Rate of Return (IRR) lebih dari tingkat discount rate $(I R R>D R)$ dan Payback Periode $(P P)$ kurang dari umur usaha $(P P<$ Umur Usaha).

Adapun analisis manfaat bersih yang diperoleh dari hasil analisis cashflow pada tahun 1 nilai Present Value $(P V)$ bernilai negatif, hal ini menunjukan bahwa penerimaan/ manfaat usaha belum mampu menutupi semua biaya yang dikeluarkan sehingga usaha tersebut belum mampu melakukan pengembalian investasi (usaha masih mengalami kerugian pada tahun pertama). Hal ini dapat dipahami karena pada tahun ke-0 perusahaan mengeluarkan biaya investasi yang besar dan pada tahun ke-1 mulai mengeluarkan biaya operasional, sedangkan perusahaan belum mampu berproduksi maksimal pada tahun pertama sehingga penerimaan yang diperoleh perusahaan belum mampu menutupi biaya yang dikeluarkan. Pada tahun ke-2 sampai tahun akhir umur usaha, produksi perusahaan mengalami peningkatan sehingga manfaat yang diterima perusahaan lebih besar daripada biaya yang dikeluarkan. Oleh sebab itu, pada tahun ke-2 sampai tahun umur usaha, nilai Present Value $(P V)$ positif, yang bahwa perusahaan sudah mendapatkan keuntungan.

\section{KESIMPULAN DAN SARAN}

\section{A. Kesimpulan}

Dari hasil analisis yang telah dilakukan pada usaha penggilingan padi PD. Ancol Jaya dapat diambil beberapa kesimpulan yaitu:

1. Berdasarkan analisis dari aspek non finansial, usaha penggilingan padi PD. Ancol Jaya layak untuk dijalankan, meskipun pada aspek lingkungan masih terdapat dampak negatif yang ditimbulkan seperti suara bising, ataupun polusi udara akibat dari proses produksi yang masih bisa ditolerir atau masih dalam batas wajar.

2. Hasil analisis aspek finansial pada usaha penggilingan padi PD. Ancol Jaya layak untuk dijalankan pada dua proyeksi atau kondisi yang berbeda yakni pada keadaan normal (kenaikan produksi 10\%) serta keadaan optimis (kenaikan produksi 25\%). Hal itu terlihat dari nilai Net Present Value (NPV) lebih dari nol yaitu sebesar Rp. 1.088.835.228,83 pada keadaan normal dan Rp. 1.604.304.738,04 pada keadaan optimis, nilai Internal Rate of Return (IRR) lebih dari tingkat discount rate $(13,5 \%)$ yaitu sebesar $64 \%$ pada keadaan normal dan $76 \%$ pada keadaan optimis, serta nilai Net Benefit/Cost (B/C) lebih besar dari satu, yakni 2,919 pada keadaan normal dan 3,646 pada keadaan optimis. Sedangkan Payback Periode $(P P)$ kurang dari umur usaha yaitu selama dua tahun lima belas hari untuk keadaan normal dan satu tahun sepuluh bulan tiga hari untuk keadaan optimis. Jadi secara finansial layak untuk dijalankan baik dalam proyeksi/ keadaan normal 
(kenaikan produksi 10\%) maupun proyeksi/ keadaan optimis (kenaikan produksi 25\%).

\section{B. Saran}

Sesuai hasil analisis kelayakan pengembangan usaha penggilingan usaha padi di perusahaan PD. Ancol Jaya, disarankan:

1. Perlu upaya perbaikan pada aspek non finansial yakni pada aspek lingkungan yang berkaitan dengan dampak negatif yang ditimbulkan, seperti suara bising dan debu yang ditimbulkan akibat dari proses produksi, ada baiknya perusahaan lebih serius dalam menangani dampak negatif yang ditimbulkan dari kegiatan usahanya. Hal tersebut bertujuan agar dampak terhadap lingkungan bisa ditekan/diminimalisir, dan tidak menimbulkan keresahan bagi masyarakat setempat.

2. Dalam pemilihan proyeksi analisis usaha pengilingan padi tersebut, perlu adanya pertimbangan yang matang seperti terjaminnya pasokan bahan baku serta keadaan keuangan perusahaan dalam kegiatan investasi yang dilakukan di awal tahun pendirian usaha tersebut. Selain itu perlu adanya komitmen pemilik perusahaan untuk menjalankan usaha tersebut dengan sebaik-baiknya guna tercapainya target keuntungan yang ingin diperoleh dimasa akhir umur usaha.

\section{DAFTAR PUSTAKA}

[1] Blanc, Leland PE., Tarquin, Anthony PE. 2008. Basic Engineering Economy, New York: Mc Graw Hill. Co.

[2] Cliffton, David, Jr., Feasibility Study. Singapore: John Wiley and Sons.

[3] Sayuti, M. 2008. Analisis Kelayakan Pabrik, Semarang: Penerbit Graha Ilmu.

[4] Siswanto, Studi Kelayakan Proyek, Jakarta: PPM.

[5] Hayzer, Jay and Render, Barry. 2008. Operational Management. $9^{\text {th }}$ ed. New Jersey: Pearson Education Edition.

[6] Umar, Husein.2001. Analisis Kelayakan Usaha. Edisi 3. Jakarta: Penerbit PT Gramedia Pustaka Utama.

[7] Thomson, Alan. 2005. Business Entrepreneurship and Innovation, the Art of Business Start-ups and Business Planning. 